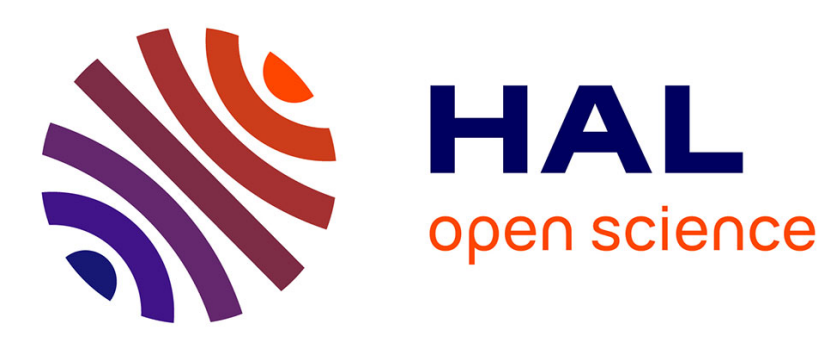

\title{
Uranium Uptake in Paracentrotus lividus Sea Urchin, Accumulation and Speciation
}

Benjamin Reeves, Maria Rosa Beccia, Pier Lorenzo Solari, Danil Smiles, David Shuh, C. Berthomieu, Didier Marcellin, Nicolas Bremond, Luisa

Mangialajo, Sophie Pagnotta, et al.

\section{To cite this version:}

Benjamin Reeves, Maria Rosa Beccia, Pier Lorenzo Solari, Danil Smiles, David Shuh, et al.. Uranium Uptake in Paracentrotus lividus Sea Urchin, Accumulation and Speciation. Environmental Science and Technology, 2019, 53 (14), pp.7974-7983. 10.1021/acs.est.8b06380 . hal-02196756

\section{HAL Id: hal-02196756 \\ https://hal.science/hal-02196756}

Submitted on 12 Feb 2020

HAL is a multi-disciplinary open access archive for the deposit and dissemination of scientific research documents, whether they are published or not. The documents may come from teaching and research institutions in France or abroad, or from public or private research centers.
L'archive ouverte pluridisciplinaire HAL, est destinée au dépôt et à la diffusion de documents scientifiques de niveau recherche, publiés ou non, émanant des établissements d'enseignement et de recherche français ou étrangers, des laboratoires publics ou privés. 
This document is confidential and is proprietary to the American Chemical Society and its authors. Do not copy or disclose without written permission. If you have received this item in error, notify the sender and delete all copies.

\section{Uranium uptake in Paracentrotus lividus sea urchin, accumulation and speciation}

\begin{tabular}{|c|c|}
\hline Journal: & Environmental Science \& Technology \\
\hline Manuscript ID & es-2018-06380c.R1 \\
\hline Manuscript Type: & Article \\
\hline $\begin{array}{r}\text { Date Submitted by the } \\
\text { Author: }\end{array}$ & 10-May-2019 \\
\hline Complete List of Authors: & $\begin{array}{l}\text { Reeves, Benjamin; Universite Cote d'Azur, ICN } \\
\text { Beccia, Maria Rosa; Universite Cote d'Azur, Institut de Chimie de Nice } \\
\text { Solari, Pier Lorenzo; Synchrotron Soleil, } \\
\text { Smiles, Danil; Chemical Sciences Division, Glenn T. Seaborg Center } \\
\text { Shuh, David; Chemical Sciences Division, Glenn T. Seaborg Center } \\
\text { Berthomieu, Catherine; CEA-Cadarache, Laboratoire des Interactions } \\
\text { Protéine Métal } \\
\text { Marcellin, Didier; CEA-Cadarache, Laboratoire des Interactions Protéine } \\
\text { Métal } \\
\text { Bremond, Nicolas; CEA, DRF/BIAM } \\
\text { Passeron Mangialajo, Luisa; COMUE Sorbonne Universites; Universite } \\
\text { Cote d'Azur, Ecomers } \\
\text { Pagnotta, Sophie; Universite Cote d'Azur, CCMA } \\
\text { Monfort, Marguerite; CEA DAM Ile de France } \\
\text { Moulin, Christophe; CEA DAM Ile de France } \\
\text { Den Auwer, Christophe; Universite Cote d'Azur, ICN }\end{array}$ \\
\hline
\end{tabular}

\section{SCHOLARONE Manuscripts}


4 Benjamin Reeves ${ }^{1,7}$, Maria Rosa Beccia ${ }^{1}$, Pier Lorenzo Solari², Danil E. Smiles ${ }^{3}$, David K. Shuh ${ }^{3}$, $5 \quad$ Catherine Berthomieu ${ }^{4}$, Didier Marcellin ${ }^{4}$, Nicolas Bremond ${ }^{4}$, Luisa Mangialajo ${ }^{5,6}$, Sophie 6 Pagnotta $^{8}$, Marguerite Monfort ${ }^{7}$, Christophe Moulin ${ }^{7}$, Christophe Den Auwer ${ }^{1}$ 


\title{
Uranium uptake in Paracentrotus lividus sea urchin, accumulation and
}

Benjamin Reeves ${ }^{1,7}$, Maria Rosa Beccia ${ }^{1}$, Pier Lorenzo Solari², Danil E. Smiles ${ }^{3}$, David K. Shuh ${ }^{3}$,

$$
\text { Pagnotta }^{8} \text {, Marguerite Monfort }{ }^{7} \text {, Christophe Moulin }{ }^{7} \text {, Christophe Den Auwer }{ }^{1}
$$

\section{(1) Université Côte d'Azur, CNRS, Institut de Chimie de Nice, UMR 7272, 06108 Nice, France}

(2) Synchrotron Soleil, L'Orme des Merisiers, Saint-Aubin, BP 48, F-91192 Gif-sur-Yvette Cedex, France

(3) Chemical Sciences Division, Lawrence Berkeley National Laboratory, Berkeley, California 94720, USA

(4) CEA, CNRS, Aix Marseille University, BIAM UMR7265, Saint Paul-Lez-Durance, France

(5) Université Côte d'Azur, Université Nice Sophia Antipolis, CNRS, FRE 3729 ECOMERS, 06108 Nice, France

(6) Sorbonne Universités, UPMC Univ. Paris 06, INSU-CNRS, Laboratoire d'Océanographie de Villefranche, Villefranche sur mer, France

(7) CEA, DAM, DIF, F-92297 Arpajon, France

(8) Université Côte d'Azur, Centre Commun de Microscopie Appliquée, 06108 Nice France

\begin{abstract}
Uranium speciation and bioaccumulation were investigated in the sea urchin Paracentrotus lividus. Through accumulation experiments in a well-controlled aquarium followed by ICP-OES analysis, the quantification of uranium in the different compartments of the sea urchin was performed. Uranium is mainly distributed in the test (skeletal components), as it is the major constituent of the sea urchin, but in terms of quantity of uranium per gram of compartment, the following rating: intestinal tract $>$ gonads $>>$ test, was obtained. Combining both extended X-ray Absorption Spectroscopy (XAS) and time resolved laser induced fluorescence (TRLFS) spectroscopic analysis, it was possible to identify two different forms of uranium in the sea urchin, one in the test, as a carbonato-calcium complex, and the second one in the gonads and intestinal tract, as a protein complex. Toposome is a major calcium-binding transferrin-like protein contained within the sea urchin. EXAFS data fitting of both contaminated organs in vivo and the uraniumtoposome complex from protein purified out of the gonads revealed that it is suspected to complex uranium
\end{abstract}


43 in gonads and intestinal tract. This hypothesis is also supported by the results from two imaging techniques 44 i.e. Transmission Electron Microscopy (TEM) and Scanning Transmission X-ray Microscopy (STXM). 45 This thorough investigation of uranium uptake in sea urchin is one of the few attempts to assess the 46 speciation in a living marine organism in vivo.

\section{INTRODUCTION}

Uranium is a natural radioelement present in the earth's crust under its natural isotope distribution ( ${ }^{\mathrm{Nat}} \mathrm{U}$ : ${ }^{238} \mathrm{U}=99.275 \%,{ }^{235} \mathrm{U}=0.719 \%$ and ${ }^{234} \mathrm{U}=0.0057 \%$ ). It is a very weak radiotoxin $\left({ }^{\mathrm{Nat}} \mathrm{U}\right.$ specific activity $=$ $25767 \mathrm{~Bq} / \mathrm{g}$ ) but most importantly, a chemical toxin, as it is able to interact with various biological targets resulting in heavy metal poisoning. Its crustal concentration ranges between 0.3 and $12 \mathrm{mg} / \mathrm{kg}$, depending on the geological composition. Due to anthropogenic activities, uranium is also present in the environment as technologically enhanced naturally occurring radioactive materials (TENORM) where mining activities are or have been implemented, mostly for nuclear fuel applications. Additional anthropogenic origins of uranium in the environment may also result from nuclear power accidents and nuclear weapons activities. ${ }^{1-}$

${ }^{3}$ Last, in some particular areas of military conflict, the use of depleted uranium in munition components has resulted in the dispersion of uranium metal into the environment. ${ }^{4}$ Most importantly, because uranium is a limited issue of public health to date (except in some specific mining or contaminated zones as mentioned above), it serves as a model (uranium is easy to manipulate in the laboratory) for more radioactive actinyls of the early actinide family, i.e., neptunyl and plutonyl, predominantly in pentavalent oxidation state $(+\mathrm{V})$ or, in specific oxidative conditions, as hexavalent (+VI).

64 In most environmental and biological conditions, uranium mainly occurs in its hexavalent oxidation state, in the form of the di-oxo uranyl cation $\left\{\mathrm{UO}_{2}{ }^{2+}\right\}$. Uranyl, if bioavailable, may compete with essential biological metal cations in binding proteins, affecting all the biological processes that depend on them. ${ }^{5}$ For example, the coordination mechanisms of uranyl with the iron binding protein transferrin has been explored several times, by Pible et al. in $2006,{ }^{6}$ by Vidaud et al. ${ }^{7}$ in 2007 , by Hemadi et al. in $2009,{ }^{8}$ and more recently by theoretical approaches by Wang et al. ${ }^{9}$ It was shown that the uranyl ion can compete with iron, which could potentially lead to the internalization of uranium in the cytoplasm of cells. However, the bioavailability and potential transfer of uranyl strongly depends on its physico-chemical speciation. For

72 instance, several studies showed that uranyl bioavailability decreases when it is bound to some inorganic

73 ligands (e.g., phosphate, carbonate) or adsorbed on colloidal and particulate matter. ${ }^{10}$ This is why it is 74 essential to deeply understand its speciation in the biosphere and biocycles, to evaluate the health risk 75 engendered on living organisms and potentially humans, through the trophic chain. 
77 Seawater comprises the largest percentage of the hydrosphere ( $c a .96 .5 \%$ ) and covers about $71 \%$ of the earth's surface. ${ }^{11}$ It is also the final environmental repository for contaminated waters from rivers and basins.

79 In oceans and seas, uranium is naturally occurring at an average concentration of around $10^{-8} \mathrm{M}$ although, 80 as for the earth's crust, heterogeneities apply. ${ }^{12}$ In 1956, Rona et al. reported a concentration of uranium 81 between 3.1 and $3.5 \mu \mathrm{g} / \mathrm{kg}$ in sea water at different locations, i.e., in the North Atlantic, the Gulf of Mexico, 82 and in the Straits of Florida. ${ }^{13} \mathrm{Ku}$ et al. reported similar values with a mean concentration of uranium of 83 about $3.3 \mu \mathrm{g} / \mathrm{L} .{ }^{14}$ Altogether uranium represents about $1 \%$ of the total radioactivity in seawater (the major 84 contributor being ${ }^{40} \mathrm{~K}$ accounting for more than $\left.90 \%\right) .{ }^{15}$ In seawater, the accumulation of several heavy 85 metals in marine organisms has been widely studied at all trophic levels. ${ }^{16-18}$ Indeed, a wide diversity of 86 organisms has been investigated, from simple organisms like algae to more complex ones like fish. It is far beyond the scope of this introduction to make an exhaustive report on this topic. Concerning radionuclides specifically, the IAEA (International Atomic Energy Agency) has continuously updated Concentration Factor (CF) values that could be used for impact calculations. ${ }^{19-20}$ The CF is defined as the ratio between the concentration of the element of interest in the studied organism and the concentration of the element in the surrounding medium. The IAEA reported values of CF for ${ }^{137} \mathrm{Cs}$ and ${ }^{90} \mathrm{Sr}$ in different species of the biota,

92 from algae to fish, and evaluated the distribution inside the organism, in multiple locations in the Baltic 93 Sea. ${ }^{19}$ Jeffree et al. recently studied the accumulation and the speciation of ${ }^{241} \mathrm{Am},{ }^{109} \mathrm{Cd},{ }^{57} \mathrm{Co},{ }^{51} \mathrm{Cr}$, ${ }^{134} \mathrm{Cs}$, $94{ }^{54} \mathrm{Mn}$ and ${ }^{65} \mathrm{Zn}$ in spotted dog fish and turbot. ${ }^{21}$ The distribution inside the organism was determined, and 95 even though similarities were observed between some of the elements, the distribution is still element96 dependent. Recently, Maloubier et al. studied the bioaccumulation of ${ }^{241} \mathrm{Am}$ and ${ }^{152} \mathrm{Eu}$ in the marine sponge 97 Aplysina Cavernicola and reported speciation data for europium. ${ }^{22}$ Some recent work has also focused only 98 on uranium. Barillet et al. showed that uranium is highly bioaccumulated in Zebrafish Danio Rerio, and 99 also that it can affect some of the biological functions, like hepatic defences. ${ }^{23}$ Eb-Levadoux et al. also 100 showed that in Zebrafish, uranium is reprotoxic due to a potential interaction with proteins. ${ }^{24}$ However, to 101 the best of our knowledge, there is no other data on uranium speciation inside marine organisms, probably 102 because of the very low concentration of this element in seawater ( $p p b$ levels), which challenges the use of 103 spectroscopic methods for speciation assessment. Nonetheless, speciation data obtained in vivo are essential 104 to shift from a large-scale descriptive approach and inventories to a well-informed biochemical mechanistic 105 approach.

In previous work, we investigated the uranium speciation in seawater, showing that in these conditions, it is mainly present as a dicalcium uranyl tricarbonate complex, $\mathrm{Ca}_{2} \mathrm{UO}_{2}\left(\mathrm{CO}_{3}\right)_{3} .{ }^{25}$ This form of uranyl has already been reported in aqueous natural systems. ${ }^{26}$ It has also been shown not to be bioavailable when it occurs in natural drinking waters. ${ }^{27}$ In the present report, we are addressing the question of uranium 
111 speciation upon bioaccumulation in sea urchin Paracentrotus lividus (Figure 1) by proceeding to in vivo 112 contamination experiments in a simplified and model biotope. We chose $P$. lividus because it is widely 113 distributed throughout the Mediterranean Sea and the north-eastern Atlantic. Moreover, P. lividus is often 114 used as a biochemical indicator of local pollution because of its sedentary habits and well-known sensitivity 115 to pollutants. It is known to accumulate heavy metals like zinc, lead, copper, iron or cadmium. ${ }^{28-29}$ For 116 instance, Warnau et al. reported the concentration of several heavy metals ( $\mathrm{Zn}, \mathrm{Pb}, \mathrm{Cd}, \mathrm{Fe}, \mathrm{Cu}, \mathrm{Cr}$ and $\mathrm{Ti}$ ) 117 in the sea grass Posidonia oceanica and in the sea urchin Paracentrotus lividus, from three different 118 locations in the Mediterranean Sea. ${ }^{30}$ They also measured the quantity of each studied metal in the three 119 different compartments of the sea urchins; the test (skeleton = shell + spines), the intestinal tract, and the 120 gonads. They reported that the metal ion accumulation changes with the body compartment. For most metal 121 ions, accumulation is ranked in the following order: digestive tube and gonads $\geq$ test. This is also what was 122 observed one year later with other elements, i.e., Ag, Cs and Am. ${ }^{31}$ Our objective here was to assess the 123 speciation of uranium in the different compartments of $P$. lividus in order to decipher the accumulation 124 biomechanisms. To do so, we first described the bio-distribution of uranium in the aquarium and within the 125 sea urchin. We have then assessed the uranium speciation in the main organs of the sea urchin (test, gonads 126 and intestinal tract) with two spectroscopic X-ray probes that are complementary, namely X-ray Absorption 127 Spectroscopy (XAS under both XANES and EXAFS regimes) and Scanning Transmission X-ray 128 Microscopy (STXM) elemental imaging. They have been combined with Time Resolved Laser 129 Fluorescence Spectroscopy (TRLFS) data and Transmission Electron Microscopy (TEM) images. In a last 130 step, the toposome protein, which is the main protein present in the sea urchin organs, was extracted and 131 purified out of the gonads. ${ }^{32}$ As the toposome is a transferrin like protein and is acting as a Ca reservoir for 132 sea urchins, it should be considered as a potential candidate for uranyl binding in the gonads. The speciation 133 of uranyl in a solution containing the purified toposome was investigated.

\section{EXPERIMENTAL SECTION}

\section{Seawater, sea urchin collection and aquarium setup}

137 Seawater was collected in the Mediterranean Sea at the Environmental Laboratory of the International

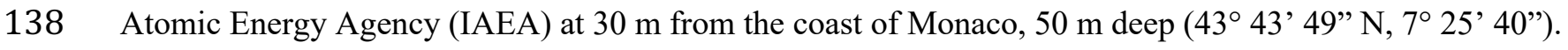
139 The seawater was filtered at $0.2 \mu \mathrm{m}$ (Whatman, GF/C grade) and sterilized by UV treatment to eliminate 140 particles and microorganisms. Commercial silica gravel $(850 \mathrm{~g})$ was placed at the bottom of the aquarium 141 filled with $10 \mathrm{~L}$ of seawater. The silica gel was needed to ensure the survivability of the sea urchins inside 142 the aquarium, and played no chemical role, nor interfered significantly with the experiments. Only one sea 143 urchin was placed in the aquarium at the same time. The aquarium was equipped with a filter and an air 
144 pump that were turned on 7 days before placing the sea urchins inside to equilibrate the whole system. The 145 seawater temperature was maintained at $16^{\circ} \mathrm{C}$ using a water-cooling system during the experiments.

146 Paracentrotus lividus sea urchins (Figure 1) were collected in Villefranche-sur-mer, by the Laboratoire 147 Océanographique de Villefranche (UMR 7093, Mediterranean Sea, France) and were fed with native algae 148 until 3 days before contamination. The food was then removed from the aquarium, and the water was cleaned 149 of any remnants before the first uranium spike. Specimens with similar size were chosen (average diameter $150=7-8 \mathrm{~cm}$, average total dry mass $=20 \mathrm{~g}$ ). All results reported in this work concern experiments performed 151 on female specimens. Each specimen used in this report is described in Table S1 of Supplementary 152 Information(SI) file.

153

\section{Spiking procedure and uranium distribution}

155 Uranium nitrate $\mathrm{UO}_{2}\left(\mathrm{NO}_{3}\right) .5 \mathrm{H}_{2} \mathrm{O}$ was directly dissolved in diluted nitric acid $(0.1 \mathrm{M})$ to obtain the $0.375 \mathrm{M}$ 156 uranium solution spike for aquarium use. Both nitric acid and uranium nitrate were of reagent grade, and 157 deionized water was used to dilute the nitric acid. Every 24 hours, $500 \mu \mathrm{L}$ of this solution were introduced 158 in the aquarium, to reach a theoretical final concentration of $[\mathrm{U}]=1.88 .10^{-4} \mathrm{M}$ after 10 days. Prior to the 159 spiking (around $10 \mathrm{~min}$ before), $500 \mu \mathrm{L}$ of a $2.10^{-4} \mathrm{M}$ solution of sodium hydroxide were introduced in the 160 aquarium to avoid any modification of the $\mathrm{pH}$. The latter was controlled using commercial $\mathrm{pH}$ paper 161 designed for seawater. The measured $\mathrm{pH}$ was around 8. The uranium concentration corresponds to a total 162 mass of uranium of $476.20 \pm 27.12 \mathrm{mg}$. It was chosen as the best compromise between uranium natural 163 concentration and EXAFS sensitivity.

164 Each sample from the aquarium (sea urchin or gravel) was rinsed with deionized water before any further 165 analysis, to remove any uranium potentially adsorbed on the sample surface, and of remnant contaminated 166 sea water, to ensure the validity of the results. The uranium content of each sample was analyzed by ICP167 OES (details are provided in SI file).

\section{Toposome extraction and purification.}

170 The toposome purification was performed according to Castellano et al. with slight modifications (details 171 are provided in SI file). ${ }^{33}$. The final concentration was estimated via UV-visible, using a calculated epsilon, 172 to be around $35 \mathrm{mg} / \mathrm{mL}(\varepsilon=1.252)$, corresponding to a molar concentration in monomer units of about 2.10-

$173{ }^{4} \mathrm{M}$. The epsilon was calculated using the sequence of amino acids published by Noll et al. ${ }^{34}$ The toposome 174 was then frozen until further use. The protein purity is estimated to be $80 \%$ minimum. The toposome is 175 probably organized in the form of trimers. The two discernible fractions under the main band probably 176 correspond to the presence of the two isoforms described at $200 \mathrm{kDa}$ and $180 \mathrm{kDa}$ for the Paracentrotus 177 lividus toposome, which are present in the nutritive phagocytes of the gonads. ${ }^{35}$ 


\section{Time Resolved Laser Induced Fluorescence spectroscopy (TRLFS)}

180 Sample preparation, sea urchin: The test was dried, then crushed into powder. The powder was directly 181 analyzed with no further preparation. Concerning the gonads, they were dried and also directly analyzed 182 with no further preparation.

183 Sample preparation, toposome-uranium complex: The same procedure as described above was used. 184 However, the uranium was this time dissolved in a solution of Tris/ $\mathrm{HCl}(10 \mathrm{mM}) \mathrm{NaCl}(10 \mathrm{mM}), \mathrm{pH} 5.5$, to 185 reduce the ionic strength of the solution ( $\mathrm{Cl}$ concentration). The solution was then kept at $4{ }^{\circ} \mathrm{C}$ until analysis. 186 Data acquisition: A Nd-YAG laser (Model Surelite Quantel) operating at $355 \mathrm{~nm}$ (tripled) and delivering 187 about $10 \mathrm{~mJ}$ of energy in a $10 \mathrm{~ns}$ pulse with a repetition rate of $10 \mathrm{~Hz}$, was used as the excitation source. 188 The laser output energy was monitored by a laser power meter (Scientech). The focused output beam was 189 directed onto the urchin part (gonad, shell) of the sea urchin (previously crushed) placed in a $1 \mathrm{~mm}$ 190 pathlength quartz cell of the spectrofluorometer (F900 Edinburgh). The detection was performed by an 191 intensified charge coupled device (Andor Technology) cooled by Peltier effect $\left(-5^{\circ} \mathrm{C}\right)$ and positioned at the 192 polychromator exit for the emission spectra measurement and by a photomultiplier tube (PMT) to measure 193 fluorescence decay time. Logic circuits, synchronized with the laser shot beam, allowed the intensifier to be 194 activated with determined time delay (from 0.005 to $1000 \mu \mathrm{s}$ ) and during a determined aperture time (from 1950.005 to $1000 \mu \mathrm{s})$. From a spectroscopic point of view, various gate delays and durations were used to ensure 196 the presence of only one complex by the measurement of a single fluorescence lifetime and spectrum. 197 Fluorescence lifetime measurements were performed by varying the temporal delay with fixed gate width.

\section{X-ray Absorption Spectroscopy (XAS) Data Acquisition and Analysis}

200 Sample preparation, sea urchins: sea urchins 2, 3 and 5 were analyzed by XAS: gonads and intestinal 201 tract for sea urchin 2 (EXAFS), only gonads for sea urchin 3 (EXAFS) and test for sea urchin 5 (X-ray 202 absorption near edge structure (XANES) (see Table S1). For sea urchin 2, gonads and intestinal tract were 203 freeze-dried for $24 \mathrm{~h}$. Solid pellets were then prepared by mixing the dry residue with polyethylene in order 204 to obtain homogenous solid pellets. For sea urchin 3, solid pellets were prepared with the gonads by mixing 205 fresh gonads with polyethylene. As polyethylene is only composed of light chemical elements, it does not 206 interfere with the EXAFS measurements. In both cases, the pellets were then kept at $-20^{\circ} \mathrm{C}$ until the analysis 207 to avoid any deterioration of the biological system. For sea urchin 5, the test was mechanically ground and 208 pressed into solid pellets. The Liebigite reference sample $\left(\mathrm{Ca}_{2} \mathrm{UO}_{2}\left(\mathrm{CO}_{3}\right)_{3}\right)$ was obtained from the 209 mineralogy collection of the Museum National d'Histoire Naturelle (MNHN), Paris, France.

210 Sample preparation, U-toposome complex: uranium nitrate was directly dissolved in $\mathrm{Tris} / \mathrm{HCl}(50 \mathrm{mM})$ $211 \mathrm{NaCl}(150 \mathrm{mM}), \mathrm{pH}=5.5$. This $\mathrm{pH}$ value prevents any visible precipitation of uranium hydroxides. Absence 
212 of hydrolysis was also verified using speciation codes. $\mathrm{pH}$ was adjusted to 5.5 with concentrated chlorhydric 213 acid. The solution was then mixed with the protein, to obtain a final concentration of uranium of $8.10^{-5} \mathrm{M}$, 214 and a concentration of protein in monomeric units estimated at 1.6. 10 $0^{-4} \mathrm{M}$. An estimated excess of protein 215 ensures that no free uranyl would remain in the solution, which would interfere with the EXAFS analysis. 216 The solution was then kept at $4^{\circ} \mathrm{C}$ until analysis.

217 EXAFS data acquisition: experiments were performed on the MARS beamline of the SOLEIL 218 synchrotron facility. Energy calibration was performed at the yttrium $\mathrm{K}$ edge at $17038 \mathrm{eV}$ and EXAFS 219 experiments at the $\mathrm{U}_{\mathrm{III}}$ edge. The MARS beamline is dedicated to the investigation of radioactive materials 220 in the hard X-ray range. ${ }^{36}$ The beamline optics consist essentially of a water-cooled double-crystal 221 monochromator (FMB Oxford), which is used to select the incident energy of the X-ray beam and for 222 horizontal focalization, and two large water-cooled reflecting mirrors (IRELEC/SESO) that are used for 223 high-energy rejection (harmonic part) and vertical collimation and focalization. All measurements were 224 achieved in fluorescence mode using a 13-element high purity germanium detector (ORTEC). The X-ray 225 absorption spectra for the test sample (from sea urchin 5) were measured at room temperature, whereas the 226 spectra for the gonad samples (from sea urchins 2 and 3) and for the intestinal tract sample (from sea urchin 227 3) were measured at $-165^{\circ} \mathrm{C}$. To perform the latter measurements, the samples were inserted in a specifically 228 designed double containment cell (H. Hermange, SOLEIL) and inserted in the dedicated liquid nitrogen 229 cryostat of the beamline. The protein sample was measured at room temperature.

230 EXAFS data processing was performed using the ATHENA code. ${ }^{37-38}$ The $\mathrm{E}_{0}$ energy was identified at 231 the maximum of the absorption edge. Fourier transform (FT) with $\mathrm{k}^{2}$ weighting was performed between 2.5 232 and $12 \AA^{-1}$ for gonads and $10.5 \AA^{-1}$ for the intestinal tract, with a Hanning window. The fits were performed 233 using the DEMETER code (version Demeter 0.9.25) and were fit in R space between 1 and $5 \AA$. EXAFS 234 data fitting: One global amplitude factor $\mathrm{S}_{0}{ }^{2}$ and one energy threshold correction factor $\Delta \mathrm{E}_{0}$ were used for 235 every path of the fits. The agreement factor $\mathrm{r}(\%)$ and the quality factor $\left(\mathrm{QF}=\right.$ reduced $\left.\chi^{2}\right)$ of the fits were 236 provided directly by DEMETER. Phases and amplitudes were calculated using the FEFF6 simulation code 237 integrated in DEMETER based on a partial structural model (in silico) of uranyl-acetate complex $238\left(\mathrm{UO}_{2} \text { (acetate }\right)_{2}$.) This model was chosen because it exhibits both monodentate and bidentate carboxylate 239 ligation to the uranyl equatorial plane. The scattering paths used for the fitting procedure are: i) simple 240 scattering paths including $\mathrm{U}-\mathrm{O}_{\mathrm{ax}}$ within the oxo bond, $\mathrm{U}-\mathrm{O}_{\mathrm{eq}}$ corresponding to the equatorial oxygen atoms 241 and $\mathrm{U}$...C corresponding to the $\mathrm{C}$ atom of the bidentate carboxylate group; ii) multiple scattering paths 242 including the quadruple path $\mathrm{U}-\mathrm{O}_{\mathrm{ax}}$ within the oxo bond, and the triple scattering $\mathrm{U}-\mathrm{O}-\mathrm{C}$ of the monodentate 243 carboxylate function. During the fitting procedure, the number of atoms of carbon in the monodentate and 244 bidentate functions was let free, in case only one coordination mode was present. The total number of 245 variables in the fit was equal to 12. 


\section{Transmission electron microscope (TEM) imaging}

248 Gonads and intestinal tract of sea urchin 2 were analysed with TEM. Directly after dissection, fresh gonads

249 and fresh intestinal tract samples were fixed for $2 \mathrm{~h}$ at room temperature with $2.5 \%$ glutaraldehyde in 250 cacodylate buffer (0.1 M, pH 7.4) in artificial seawater, then washed with $0.1 \mathrm{M}$ cacodylate buffer (pH 7.4)

251 and post-fixed with $1 \%$ osmium tetroxide in cacodylate buffer containing $1 \%$ potassium ferrocyanide. The 252 samples were embedded in Epon resin after dehydration using an acetone/water solution and then acetone. 253 Ultrathin sections (70-80 nm) were cut using a diamond diatom mounted on an ultramicrotome (Ultracut $\mathrm{S}$, 254 Leica) and placed on copper TEM grids coated with formvar film. Sections were observed with a JEOL 255 JEM 1400 TEM equipped with a CCD camera (Morada, Olympus SIS) at the Centre for Applied Microscopy 256 (CCMA, University of Nice Sophia Antipolis, Nice, France).

\section{Scanning transmission X-ray microscope (STXM) imaging}

Sample preparation: Gonad and intestinal tract cells of sea urchin 2 were analysed with STXM. The STXM samples were prepared as described above for TEM analysis. Sections of 70-80 nm were placed on a $100 \mathrm{~nm}$ thick $\mathrm{Si}_{3} \mathrm{~N}_{4}$ membrane window (1 mm square) in a $10 \mathrm{~mm}$ frame obtained from Silson Ltd. A second $\mathrm{Si}_{3} \mathrm{~N}_{4}$ window was glued over the first to seal and confine the sample for radiological control purposes.

Data acquisition: Data was recorded with the STXM on beamline 11.0.2 of the Advanced Light Source (ALS) located at the Lawrence Berkeley National Laboratory in Berkeley, USA. ${ }^{39}$ The STXM methodology monochromator was performed at the neon K-edge $(867.3 \mathrm{eV})$. The STXM measurements were performed current of $500 \mathrm{~mA}$. Images at a single energy were obtained by raster scanning the sample and collecting $\mathrm{X}$-rays as a function of sample position. Elemental maps of uranium were obtained by subtracting an image taken before the absorption threshold from an image obtained at resonance utilizing the $\mathrm{U} \mathrm{N}_{5}$ transition

$272(\sim 738 \mathrm{eV})$, following image alignment.

273 Data treatment: Data treatment was performed with the aXis2000 code developed at McMaster 274 University. ${ }^{42}$

275

\section{RESULTS AND DISCUSSION}

\section{Uranium uptake and distribution in the organs.}

278 We have investigated the uptake of uranium by P. lividus in the closed aquarium system described in the 279 experimental section (1 spike per day for 10 days). Four similar experiments have been conducted with five 
280 sea urchins that are detailed in Table S1. A control experiment with no spike was also performed at the same 281 time in a similar aquarium next to the one used for contamination. It showed that no detectable uranium was 282 naturally present in sea urchins (below the detection limit of ICP-OES, about $1 \times 10^{-7} \mathrm{mg} / \mathrm{L}$ ). Each P. lividus 283 specimen was sacrificed and dissected at the end of the 10 days. Gonads, digestive tube and test were 284 separated, and uranium content was measured by ICP-OES.

285 First, the total uranium balance was measured in the entire system with sea urchin 4 to ensure that the 286 major part of the uranium was distributed within the main components (sea water, gravel, sea urchin), and 287 not, for instance, adsorbed on the aquarium wall or filter. The concentration of uranium in each of the 288 different system components was measured. The results are presented in Figure S1. From the concentration 289 in seawater, the global Concentration Factor (CF) of sea urchin 4 for an exposure of 10 days was calculated 290 and is $0.37 \pm 0.02$.

291 The bioaccumulation of uranium in each compartment of the sea urchin (test, gonad, intestinal tract) has 292 been assessed. Although competition between uranium and other cations was not explicitly taken into 293 account, the use of a natural medium implies that competition is implicitly included. It is presented in Figure 2942 for sea urchins 1, 2 and 4 as the fraction of total uranium mass per dry weight of each compartment (see 295 Table S2). In the three specimens, the concentration in the digestive tube is almost 3 times and 10 times 296 higher than in the gonads and test, respectively. Differences can be observed between sea urchin 4 and the 297 two others. We explain these discrepancies by the seasonal variations in the gonads quantity and the seasonal 298 variations in the concentration of proteins inside the gonads. Indeed, the experiment on sea urchin 4 was 299 conducted out of the reproduction season (February-May), which was not the case for sea urchins 1 and 2. 300 Partial concentration factors for each compartment may also be calculated. The following CF were obtained 301 for sea urchin 1: $\mathrm{CF}_{\text {gonads }}=1.0 \pm 0.07, \mathrm{CF}_{\text {intestin }}=2.8 \pm 0.1$ and $\mathrm{CF}_{\text {test }}=0.25 \pm 0.02$. The overall very low value 302 obtained for the entire specimen is largely due to the low value of $\mathrm{CF}_{\text {test }}$ that is associated to the largest mass 303 of the specimen (the test). These results are in agreement with the values reported by Warnau et al. in 1996 304 as the same ordering was observed for most heavy metals: gonads, intestinal tract $>>$ test. In their 305 communication, the concentration measured in the intestinal tract is the highest of the three compartments 306 for several heavy metals as iron, copper, tin and mercury. However, the gonads are more concentrated in 307 zinc than the intestinal tract, which means that the distribution is element specific and also confirms that 308 speciation is playing a key role in the accumulation mechanisms. In addition, Warnau et al. also highlighted 309 the fact that the concentrations of every metal but lead are always lower in the test than the gonads or the 310 intestinal tract, no matter which of the two latter compartments is the most concentrated. These data clearly 311 highlight the necessity of speciation investigation in each compartment separately, as the accumulation rate 312 of uranium is radically different between the three compartments. 


\section{Uranium speciation in the test}

315 The test of sea urchin is mainly composed of monocrystalline calcite (calcium carbonate) rich in 316 magnesium. ${ }^{43}$ Uranium accumulation in test and spines is very low, as mentioned above, with an average 317 concentration of $11 \mathrm{ppm}\left(\mathrm{CF}_{\text {test }}=0.25 \pm 0.02\right)$. Such a concentration lies just above the estimated EXAFS 318 detection limit under our experimental conditions. Therefore, an EXAFS spectrum could not be recorded 319 from the test with a reasonable signal to noise ratio and only the XANES part of the spectrum was 320 significant. Figure 3 compares the XANES spectra of the test after in vivo contamination of sea urchin 5 321 with data acquired from a Liebigite $\left(\mathrm{Ca}_{2} \mathrm{UO}_{2}\left(\mathrm{CO}_{3}\right)_{3}\right)$ solid state reference. Liebigite is taken here as the 322 model for the main species of uranium in seawater, the dicalcic uranyl tricarbonate species, $\mathrm{Ca}_{2} \mathrm{UO}_{2}\left(\mathrm{CO}_{3}\right)_{3}$. 323 The enlarged insert of Figure 3 shows the derivatives of the spectra. A qualitative comparison of both 324 XANES spectra and their derivatives for the test samples and the Liebigite reference suggests that the 325 speciation of uranium in the test is similar to that in the Liebigite model, although it is not definite proof. 326 This could signify that a sorption mechanism occurs and is at the origin of the uranium accumulation in the 327 test. As adult spines do not grow once they reach their adult size, a mechanism involving sorption on the 328 calcite monocrystalline surface of the spines followed by slow diffusion of uranium inside the calcite 329 structure agrees well with the final very low concentration of uranium in the test, contrary to a mechanism 330 of incorporation of the uranium during the growth of the spines. To complement the XANES results, TRLFS 331 measurements were also performed on sea urchin 5. The wavelengths of the maximum of fluorescence 332 emissions obtained are 471, 488, 507, 528 and $552 \mathrm{~nm}$ (Figure 4). Previous studies on uranium compounds $\mathrm{s}^{25}$ 333 report the wavelengths obtained for different species, including uranium in seawater, several carbonated 334 calcium-uranium complexes, and sulphate and phosphate uranium complexes. Indeed, a slight 335 hypsochromic shift is noticed here, mainly for the higher wavelengths compared to free uranyl (reported 336 wavelengths: 470-488-509-534-559 nm), which is characteristic of $\mathrm{M}_{\mathrm{x}}-\mathrm{UO}_{2}-\left(\mathrm{CO}_{3}\right)_{\mathrm{y}}$ complexes (with $\mathrm{x}$ : 337 1-2 and $\mathrm{y}: 2-3)$, with $\mathrm{M}=\mathrm{Ca}^{2+}, \mathrm{Mg}^{2+}$ and $\mathrm{Sr}^{2+}$.

338 Even though it is not possible to differentiate all the possible species, the results above are consistent with 339 the presence of the dicalcic uranyl tricarbonate species in the test at a relatively low level.

\section{Uranium accumulation in the gonad and intestinal tract cells, imaging and spectroscopy}

342 Transmission electron microscope (TEM) imaging was performed on the gonad cells of contaminated sea 343 urchin 2. Figure 5 shows a large field TEM image of the gonads. More specifically, two types of cells can 344 be observed; the reproductive cells (circular and darker), and the storage cells (various shapes, lighter). No 345 evidence of uranium precipitates can be noted on this micrograph in any of the cells although uranium is 346 present in the gonads at a concentration of around $50 \mathrm{ppm}$, as mentioned before. Precipitates of uranium 347 phosphate phases have been observed for different bacterial systems. For instance, Suzuki et al. reported 
348 that nanoprecipitates of uranium were visible extra-cellularly in Deinococcus radiodurans after exposure. ${ }^{44}$ 349 Uranium-phosphate crystals were also reported to be present inside cells of Stenotrophomonas Maltophilia 350 by Merroun et al. ${ }^{45}$ It was also observed in living cells UMR-106, which are model osteoblastic cells. ${ }^{46}$ The 351 absence of any visible precipitate, although not a definite proof, suggests that uranyl is not incorporated as 352 an insoluble mineral phase. To further investigate this assumption, STXM elemental imaging was performed 353 on gonads cells of the same sea urchin specimen. Figure 6 shows the STXM image recorded at $738 \mathrm{eV}$, just 354 above the uranium $\mathrm{N}_{\mathrm{V}}$ edge. One can clearly distinguish the cell membrane and the different organelles 355 inside. The elemental map was then obtained via alignment and subtraction of the STXM image collected 356 at an energy preceeding the $\mathrm{N}_{\mathrm{V}}$ edge at $725 \mathrm{eV}$ (Figure S5). The elemental map reveals a featureless map 357 with a shadow ring at the location of the cell wall although the contrast in the shadow ring is noticeable but 358 only $2 \%$ above background. Thus, the elemental map shows that uranium is not localized in specific hot 359 spots or precipitates to our degree of both spatial and spectral resolution but may be homogeneously 360 distributed around the cell membrane. As a consequence, both TEM and STXM images suggest that uranium 361 may be complexed within the cell by proteins, enzyme or metabolites even though this is clearly not a 362 definitive evidence because only a limited number of cells were observed and the signal of the shadow ring 363 in the uranium elemental map is very weak.

364 Considering the affinity of uranyl for hard donor oxygen groups like in the transferrin binding site 365 (aspartate, tyrosine, carbonate) $)^{7,47}$, complexation of the uranyl cation by carboxylate rich proteins, enzyme 366 or metabolites is a reasonable assumption. This could also explain the low contrast observed in the STXM 367 contrast image because it would be distributed over the entire cell membrane. Such ligation could involve 368 aspartic, glutamic or tyrosine residues, for instance. To further determine the speciation of uranium inside 369 the cells and possible complexation, contaminated gonads of sea urchin 2 and 3 were analysed by EXAFS 370 and XANES spectroscopy at the uranium $L_{\text {III }}$ edge. The XANES spectrum of the gonads of sea urchin 2 is 371 provided in Figure 3 and exhibits the expected uranyl pattern. The EXAFS spectra obtained for the gonades 372 of sea urchins 2 and 3 are presented in Figure 7. The experimental spectrum for sea urchin 2 was adjusted 373 with a model composed of 3 scattering shells $\left(\mathrm{O}_{\text {yle }}, \mathrm{O}_{\text {eq }}\right.$ and $\left.\mathrm{C}\right)$ as explained in the experimental section (the 374 spectrum corresponding to sea urchin 3 being superimposable, but at lower signal to noise ratio, is shown 375 but not fitted). The best fit metrical parameters are reported in Table 1, the Fourier transform (modulus and 376 imaginary parts) is provided in Figure S6. The first shell corresponds to the two axial oxygen atoms typical 377 of the uranyl oxocation. The second shell is composed of 5.1(3) $\mathrm{O}$ atoms at 2.37(1) $\AA$ (average) and the last 378 shell is composed of 3.3(9) C atoms at 2.94(3) A. Such a coordination sphere is indeed typical of carboxylate 379 rich biomolecules, although a detailed path by path analysis is not possible here in the absence of a specific 380 structural model. Alternative attempts to fit our data with a Liebigite model lead to unrealistic metrical 381 parameters, thus supporting protein or metabolite complexation. Pible et al. in 2006 studied the interaction 
382 between uranyl and a wide number of proteins. ${ }^{6}$ They calculated and reported the distances between uranium 383 and selected protein structures containing uranyl. Values for the $\mathrm{U}-\mathrm{O}_{\mathrm{eq}}$ distances fall into the range 2.31 $3842.61 \AA$ for monodentate carboxylate groups and $2.41-2.84 \AA$ for bidentate carboxylate groups. In the 385 specific case of transferrin, Hémadi et al. in 2009 and Wang et al. more recently reported the binding 386 mechanism of uranyl to transferrin by DFT calculations. ${ }^{8-9}$ In the model of Wang, the most probable 387 coordination sphere is composed of one bidentate carbonate with U-O at $2.46 \AA$, two tyrosines with U-O at $3882.30 \AA$, and one monodentate aspartate at a distance of $2.44 \AA$. The values we obtained for the U-O $\mathrm{eq}_{\text {eq }}$ average 389 distance (reported in Table 1) seems to indicate the presence of monodentate carboxylate groups although 390 only average values are discussed here. Concerning the carbons atoms, the U...C average distances reported 391 in Table 1 in the range 2.9 - $3.0 \AA$ also support the presence of bidentate carboxylate functions. No evidence 392 of monodentate complexation was found using the U...C interaction. However, this is not an absolute proof, 393 considering that this interaction is often very weak, due to the angle of the U-O-C bond (deviating from 394 focusing effect optimum angle, $180^{\circ}$ ) in monodentate configuration. On the other hand, the triple scattering 395 path U-C-O was found to be necessary to fit the experimental data. This path being a fingerprint of 396 monodentate ligation, it suggests the occurrence of at least one monodentate carboxylate function. We thus 397 propose here the following mode of coordination: two atoms of oxygen (for the oxo bonds), a mix of 398 monodentate and bidentate carboxylate functions with an unknown ratio, and possibly one water molecule 399 to complement the equatorial coordination sphere. The above structural data therefore suggest that uranyl 400 is coordinated to carboxylate residues of a protein or metabolite.

401 As for the gonad cells, the EXAFS (Figure 7) and XANES (Figure 3) spectra at the $\mathrm{L}_{\text {III }}$ edge of uranium 402 was recorded for the intestinal tract cells of sea urchin 2. Qualitatively, the spectra are very similar to what 403 is discussed above, suggesting that the same type of complexation occurs in this compartment as well. 404 Experimental and simulated EXAFS spectra are displayed in Figure 7, best fit structural parameters are also 405 reported in Table 1. The U-O $\mathrm{O}_{\text {eq }}$ average distance $(2.35(1) \AA)$ is similar to those obtained for the gonad cells 406 (2.37(1) $\AA$ ) and the same type of U...C path has been used. This suggests that the same biomolecule (or 407 same type) is involved in the uranium complexation in the intestinal tract.

408 In addition, TRFLS measurements were also performed (Figure 4) on the gonads of sea urchin 5. The 409 following fluorescence wavelengths were obtained: 501-521-542 nm. In contrast to what was obtained for 410 the test, a bathochromic effect with respect to free uranyl (488-509-534 nm) is observed, together with two 411 lifetimes of $140 \mu$ s and $1600 \mu$ s without modification of the spectra. This indicates that the carbonato calcite 412 form of uranyl is not the correct speciation within the gonads, as already supported by the EXAFS data 413 fitting. Bathochromic effects have been reported to occur in the presence of complexing ligands, such as 414 sulphate or phosphonate, the latter leading to the largest shift (main wavelengths: 496-519-545). In the 415 present case, the shift is even more important taken together with the broadening of the spectrum, indicating 
416 that most of the uranyl is likely to be complexed with a strong complexing ligand with multiple interaction

417 sites such as macromolecules that establish several local environments (and account for the broadening

418 observed as well as the different lifetimes).

In conclusion, the best fit EXAFS data support the hypothesis of a complexation of the uranyl with carboxylate rich proteins, enzymes or metabolites in gonads and intestinal tract cells. This assumption is

422 also in full agreement with both STXM and TEM imaging.

\section{Uranium-toposome complexation}

The toposome is the main protein in sea urchins and is present in both the gonads and intestinal tract. It is described as a multimer of $180 \mathrm{kDa}$ monomers, known as $22 \mathrm{~S}$ fragment. ${ }^{48}$

427 This protein, also referred to as major yolk protein, was previously identified as a calcium binding iron-

428 less transferrin like protein. ${ }^{35}$ As a consequence, toposome is a potential candidate for uranyl complexation 429 in the cells. Different final masses are reported, depending on the number of monomers (from 1 to 6). As a 430 consequence, toposome is a potential candidate for uranyl complexation in the cells.

431 Following toposome extraction from gonad cells and purification, the EXAFS spectrum at the $\mathrm{L}_{\text {III }}$ edge of 432 uranium was recorded for the U-toposome complex in solution. The experimental XANES data, the 433 experimental EXAFS spectra and the best simulated EXAFS spectra are similar to both gonads and intestinal 434 tract spectra although some slight differences appear between 6 and $9 \AA^{-1}$ (Figure 7). Nonetheless, the 435 similarities between the best fit structural parameters (reported in Table 1) obtained for the three systems 436 strongly suggest that the toposome protein is a good match for uranyl complexation in those two 437 compartments. The slight differences observed in the EXAFS spectra, notably in the wave between 6 and 9 $438 \AA^{-1}$ are not due to differences in the nature of the binding site (like carboxylate versus phosphate ligation for 439 instance) but most probably to differences in conformation as indicated by the similarities of the imaginary 440 parts of the moduli of the FT (Figure S6).

441 TRFLS measurements were also performed on a U-toposome solution $\left(2: 1\right.$ ratio, $\left.\left[\mathrm{UO}_{2}\right]=1 \mu \mathrm{M}\right)$. The 442 spectrum represented in Figure 4 exhibits the same fluorescence wavelengths as observed before (501-521$443542 \mathrm{~nm}$ ). However, two other fluorescence wavelengths must be highlighted: $485 \mathrm{~nm}$ and $465 \mathrm{~nm}$, the latter 444 being characteristic of carboxylic functions. This validates the EXAFS interpretation for the U-toposome 445 complex and suggests that the speciation of uranyl in the toposome complex and in gonads and intestinal 446 tract cells is similar. The absence of the $465 \mathrm{~nm}$ wavelength in the gonad TRLFS spectrum may be explained 447 because the gonads are not only composed of toposome, even though it is the main protein. Other proteins 448 or metabolites and thus other complexation conformations might be present. The spectrum obtained for 449 gonads is in consequence less specific. 
451 The fact that the toposome is likely to complex uranyl inside the sea urchin is a result of great interest, as it 452 is a strong evidence of the metabolization of uranyl inside a living organism, from a dicalcic carbonato form 453 in seawater to a protein complex inside the sea urchin. This shows the importance of speciation as a key 454 parameter to understand and evaluate the potential impact on the environment and on humans that this 455 element, and by extension, other similar elements, can have, if released in the environment. There is still an 456 important need to continue these studies, as the speciation of multiple radioisotopes in biocycles remains 457 completely unknown.

\section{Associated content}

460 The Supporting Information is available free of charge on the ACS Publications website at ...

461 The SI contains Table S1, which describes the different measurements on the 5 sea urchins. Results dealing 462 about the distribution of the uranium inside the sea urchin organs and inside the aquarium (Table S2 and 463 Figure S1). Elution profiles and SDS gel are presented Figure S2, S3 and S4. Complementary STXM images 464 and EXAFS data are also presented (Figure S5 and S6).

\section{Author information}

467 Corresponding author:

468 *C. Den Auwer, Phone: +0033, E-mail : christophe.denauwer@univ-cotedazur.fr

469 The authors declare no competing financial interest.

470

\section{ACKNOWLEDGMENTS:}

472 This work was financed by the DNP (Direction of Nuclear Propulsion) of CEA DAM. We thank the 473 International Atomic Energy Agency, Environmental Laboratory of Monaco for providing the seawater. We 474 also acknowledge the LOV, UMR 7093 for providing the sea urchins and the algae. The XAS experiments 475 were performed at the MARS beamline of the SOLEIL synchrotron facility, Gif sur Yvette, France. This 476 research was supported in part (DES, DKS) by the Director, Office of Science, Office of Basic Energy 477 Sciences, Division of Chemical Sciences, Geosciences, and Biosciences Heavy Elements Chemistry 478 program of the U.S. Department of Energy under Contract Number DE-AC02-05CH11231 at Lawrence 479 Berkeley National Laboratory (LBNL). This research used resources of the Advanced Light Source, which 480 is a U.S. Department of Energy Office of Science User Facility supported under Contract No. DE-AC02481 05CH11231 at LBNL. Finally, we thank the Centre Commun de Microscopie Appliquée for the SEM 482 imaging. 
484 Table 1: Best fit parameters for EXAFS data from the $\mathrm{U}_{\mathrm{III}}$ edge. Numbers in brackets are the estimated 485 uncertainties, numbers in italics have been fixed. $\sigma^{2}$ is the Debye Waller factor of the considered scattering 486 path. $\mathrm{S}_{0}{ }^{2}$ is the global amplitude factor, $\mathrm{e}_{0}$ is the energy threshold, $\mathrm{R}_{\text {factor }}$ is the agreement factor of the fit in $487 \%$ and $\mathrm{Q}$ is the quality factor (reduced $\mathrm{CHI}^{2}$ ) of the fit.

488

489

Sea First coordination

Second

Third

Fit

\begin{tabular}{|c|c|c|c|c|}
\hline urchin 2 & shell & coordination shell & coordination shell & parameters $^{\mathbf{a}}$ \\
\hline Gonads & $\begin{array}{l}2 \mathrm{O}_{\mathrm{ax}} \\
\text { at } 1.79(1) \AA, \\
\sigma^{2}=0.003 \AA^{2}\end{array}$ & $\begin{array}{l}5.1(3) \mathrm{O}_{\mathrm{eq}} \\
\text { at } 2.37(1) \AA, \\
\sigma^{2}=0.008 \AA^{2}\end{array}$ & $\begin{array}{l}3.3(9) \mathrm{C} \\
\text { at } 2.94(3) \AA \\
\sigma^{2}=0.007 \AA^{2}\end{array}$ & $\begin{array}{l}S_{0}^{2}=1.00 \\
\mathrm{e}_{0}=1.56 \mathrm{eV} \\
\mathrm{R}_{\text {factor }}=1.6 \% \\
\mathrm{Q}=2\end{array}$ \\
\hline $\begin{array}{l}\text { Intestinal } \\
\text { tract }\end{array}$ & $\begin{array}{l}2 \mathrm{O}_{\mathrm{ax}} \\
\text { at } 1.79(1) \AA, \\
\sigma^{2}=0.007 \AA^{2}\end{array}$ & $\begin{array}{l}5.8(8) \text { Oeq } \\
\text { at } 2.34(1) \AA, \\
\sigma^{2}=0.010 \AA^{2}\end{array}$ & $\begin{array}{l}3.8(7) \mathrm{C} \\
\text { at } 2.96(5) \AA, \\
\sigma^{2}=0.001 \AA^{2}\end{array}$ & $\begin{array}{l}S_{0}^{2}=1.00 \\
\mathrm{e}_{0}=3.34 \mathrm{eV} \\
\mathrm{R}_{\text {factor }}=2.2 \% \\
\mathrm{Q}=4\end{array}$ \\
\hline Toposome & $\begin{array}{l}2 \mathrm{O}_{\mathrm{ax}} \\
\text { at } 1.78(1) \AA, \\
\sigma^{2}=0.003 \AA^{2}\end{array}$ & $\begin{array}{l}5.5(9) \text { Oeq } \\
\text { at } 2.35(2) \AA \\
\sigma^{2}=0.011 \AA^{2}\end{array}$ & $\begin{array}{l}3.4(7) \mathrm{C} \\
\text { at } 2.89(3) \AA \\
\sigma^{2}=0.001 \AA^{2}\end{array}$ & $\begin{array}{l}S_{0}^{2}=1.10 \\
\mathrm{e}_{0}=3.29 \mathrm{eV} \\
\mathrm{R}_{\text {factor }}=2.2 \% \\
\mathrm{Q}=12\end{array}$ \\
\hline
\end{tabular}

490

491

492 


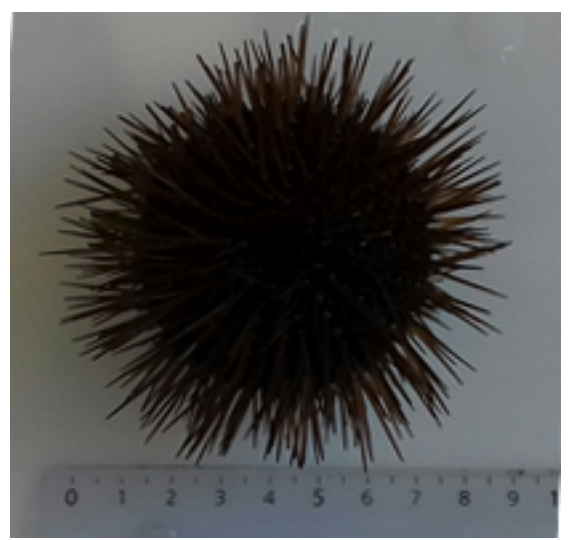

493

494

495

496

Figure 1: Picture of a sea urchin Paracentrotus lividus (one unit = one centimeter).

497

498

499 


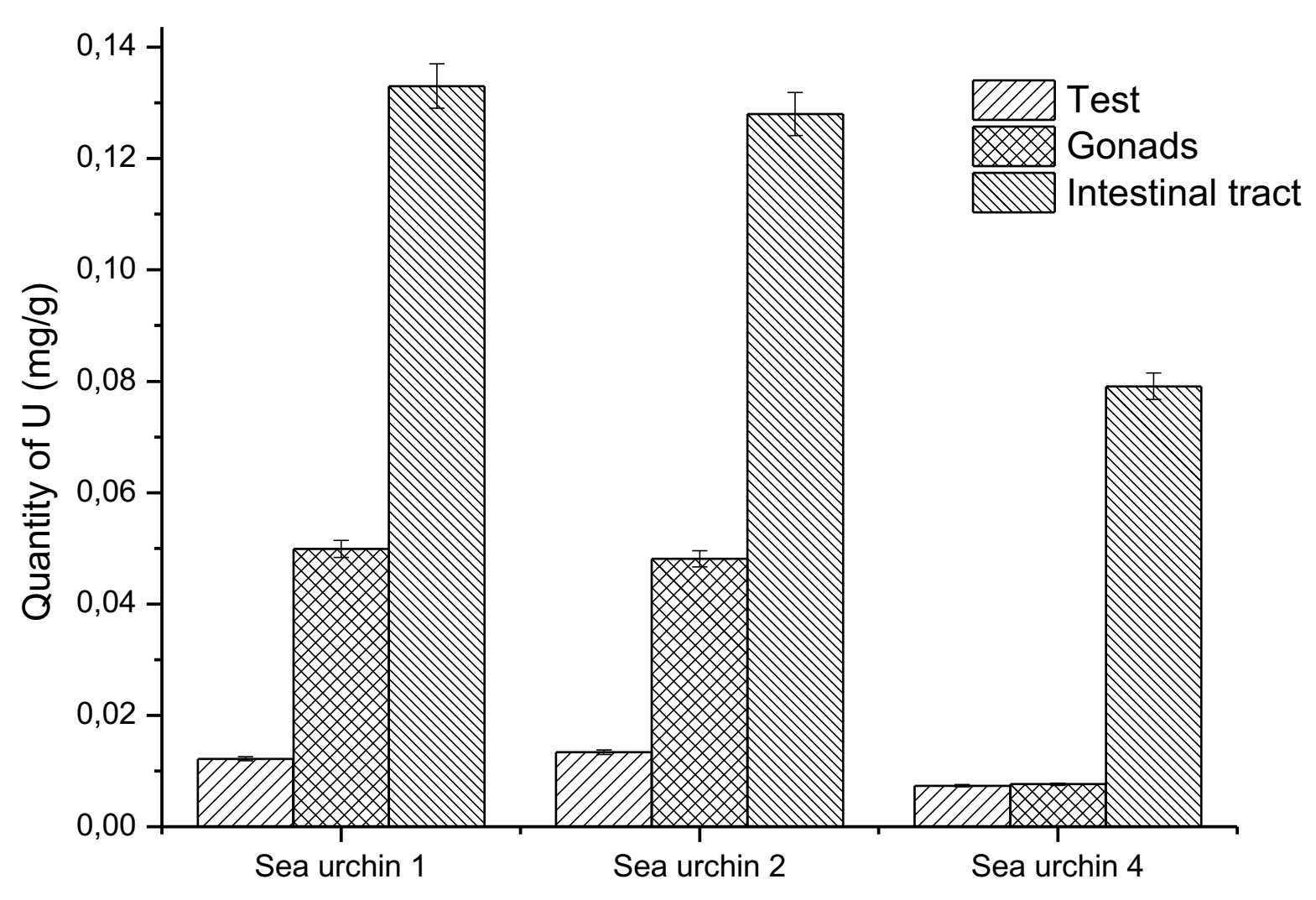

500

501

502

503 Figure 2: Uranium concentration (in $\mathrm{mg} / \mathrm{g}$, elemental $\mathrm{U}$ ) for the three compartments of the sea urchins 1,2 504 and 4.

505 


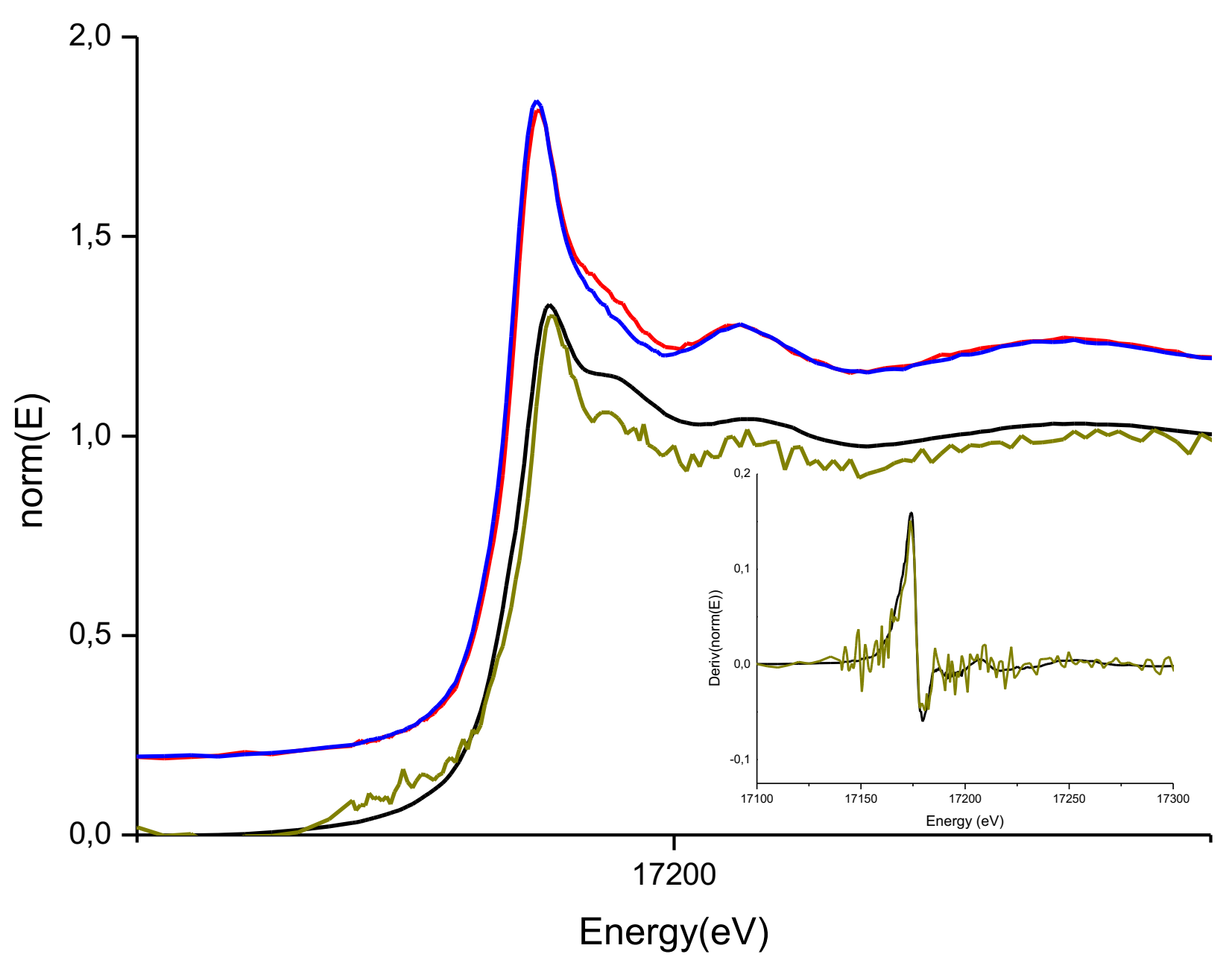

Figure 3: XANES spectra at the U LIII edge of the test of sea urchin 5 (green), of the Liebigite reference sample (black), of the gonads (red) and the intestinal tract (blue) of sea urchin 2 (both shifted in ordinates for clarity). Insert: Enlargement of the corresponding first derivatives of the test and the Liebigite reference sample. 


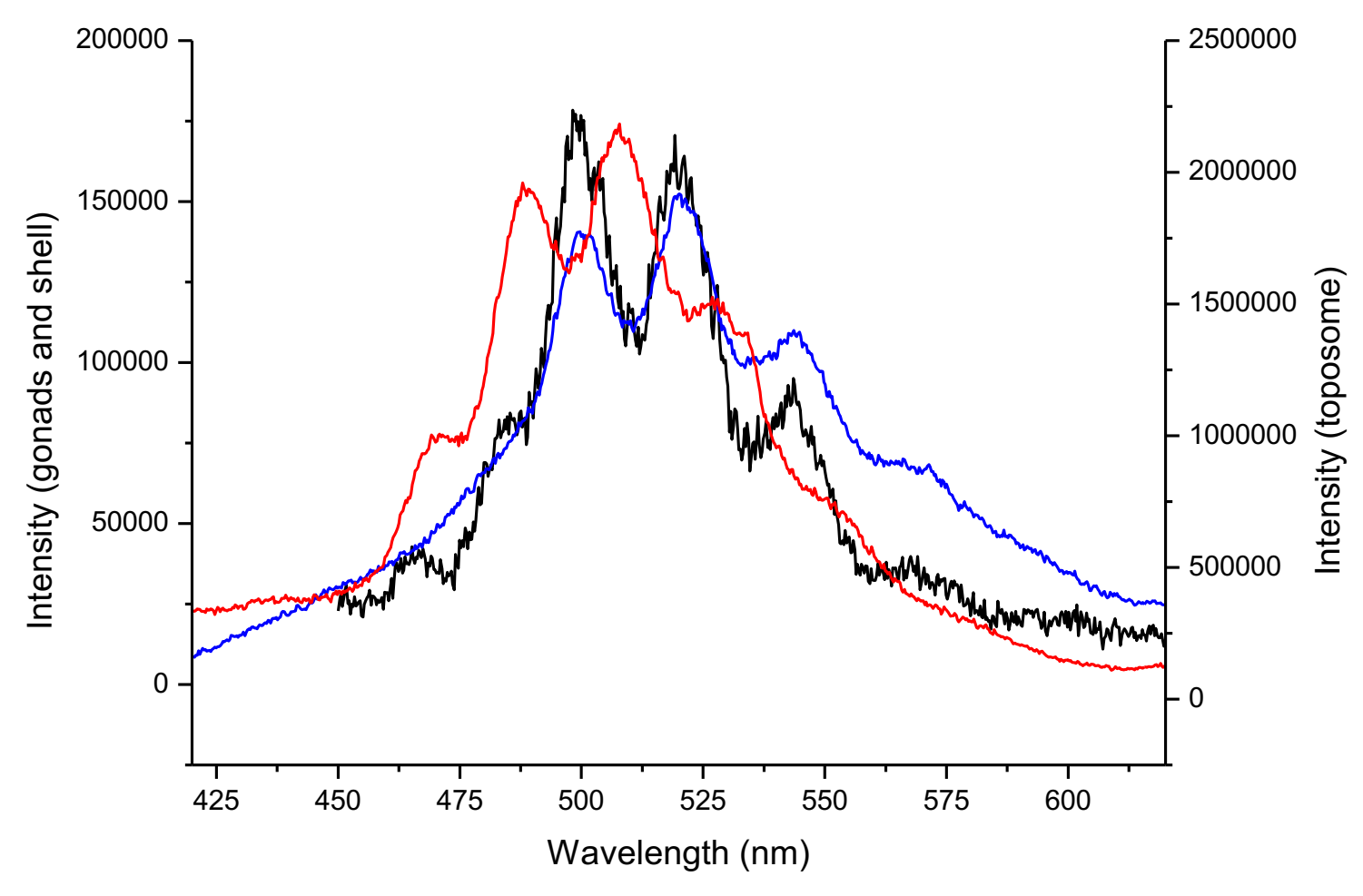

509 Figure 4: TRFLS spectra obtained for the contaminated test of sea urchin 5 (red), for the contaminated 510 gonads of sea urchin 5 (blue) and U-toposome complex (black)

511

512

513 


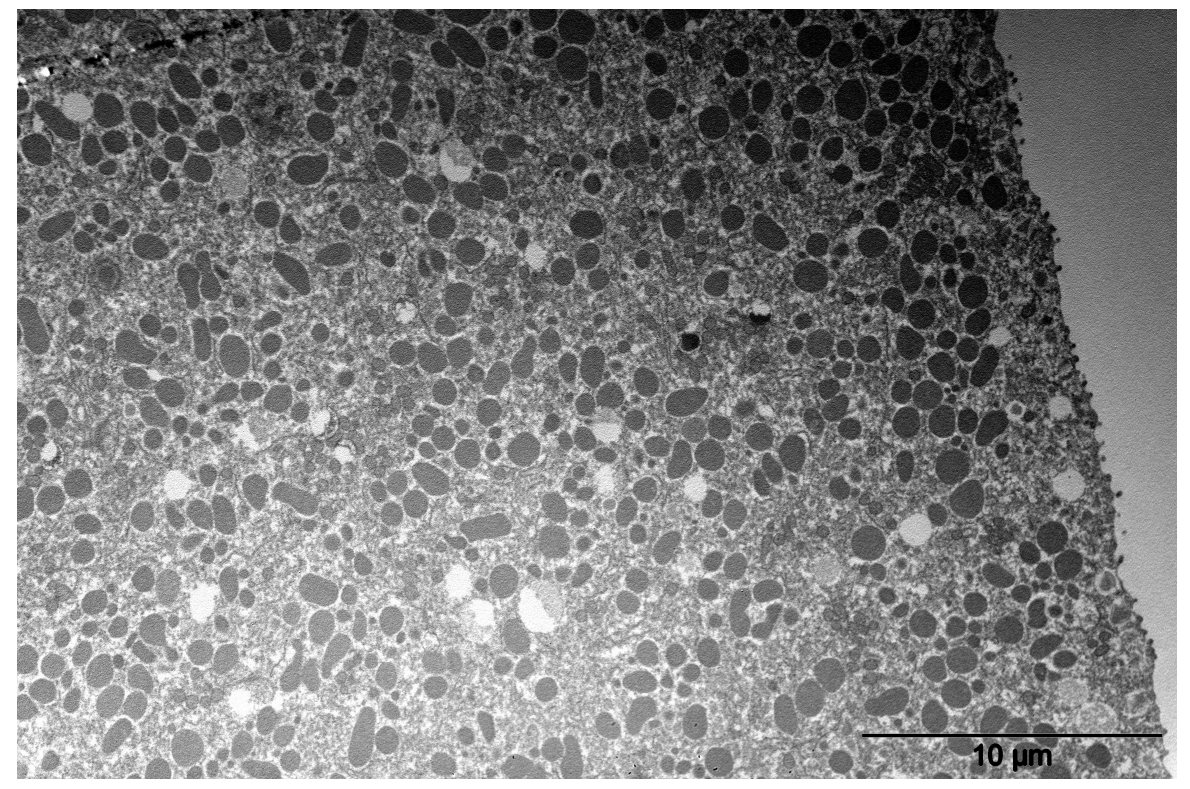

Figure 5: TEM imaging performed on the gonads of sea urchin 2.

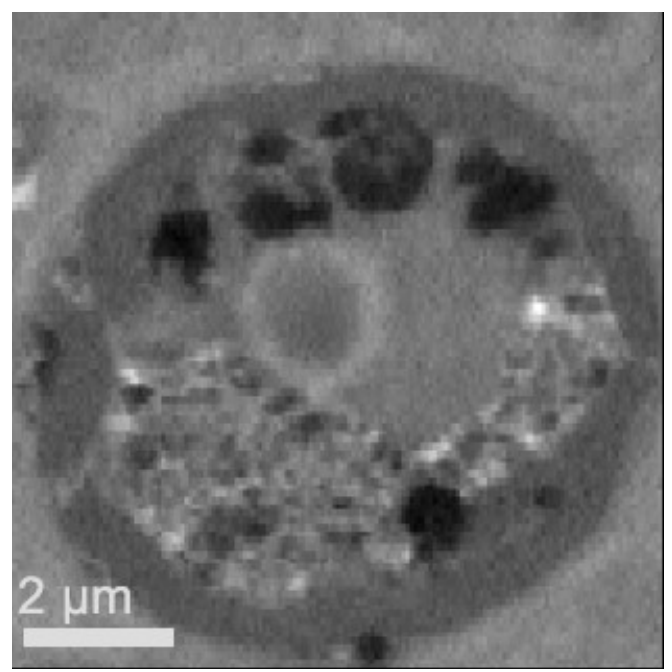

Figure 6: STXM normal contrast image of the sea urchin 2 gonad cells collected at $738 \mathrm{eV}$.

514

515

516

517

518

519 


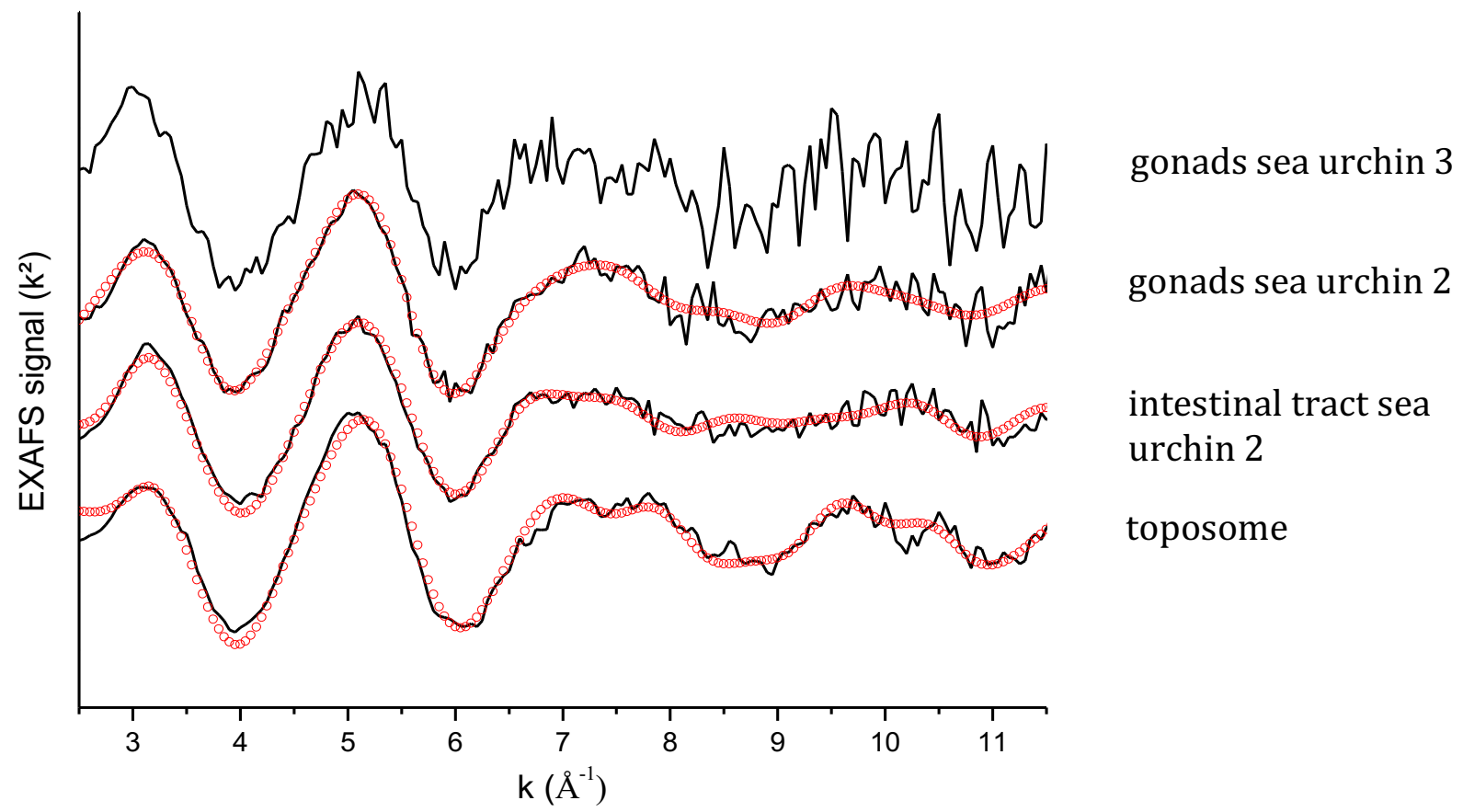

Figure 7 : EXAFS spectra $\left(\mathrm{k}^{2}\right)$ at the $\mathrm{U}_{\mathrm{III}}$ edge of the contaminated intestinal tract of sea urchin 2 (SU2) and the U-toposome complex. The EXAFS spectra obtained for the contaminated gonads of sea urchin $3(\mathrm{SU} 3)$ is also presented. Experimental $=$ straight line; fit $=$ red dots.

528 
529

530

531

532

533

534

535

536

537

538

539

540

541

542

543

544

545

546

547

548

549

550

551

552

553

554

555

556

557

558

559

560

561

562

563

564

565

566

567

568

569

570

571

572

573

574

575

576

577

578

\section{References:}

[1] Pereira R., Barbosa S., Carvalho F.P., Uranium mining in Portugal: a review of the environmental legacies of the largest mines and environmental and human health impacts. Environ. Geochem. Health 2014, 36 (2), 285-301.

[2] Wendel C.C., Fifield L.K., Oughton D.H., Lind O.C., Skipperud L., Bartnicki J., Tims S.G., Høibråten S., Salbu B., Long-range tropospheric transport of uranium and plutonium weapons fallout from Semipalatinsk nuclear test site to Norway. Environ. Int. 2013, 59, 92-102.

[3] Abe Y., Iizawa Y., Terada Y., Adachi K., Igarashi Y., Nakai I., Detection of uranium and chemical state analysis of individual radioactive microparticles emitted from the Fukushima nuclear accident using multiple synchrotron radiation X-ray analyses. Anal. Chem. 2014, 86 (17), 8521-8525.

[4] Bleise A., Danesi P.R., Burkart W., Properties, use and health effects of depleted uranium (DU): a general overview. J. Environ. Radioactiv. 2003, 64 (2-3), 93-112.

[5] Michon J., Frelon S., Garnier C., Coppin F., Determinations of Uranium (VI) Binding Properties with some Metalloproteins (Transferrin, Albumin, Metallotionein and Ferritin) by Fluorescence Quenching. $J$. Fluoresc 2010, 20 (2), 581-590.

[6] Pible O., Guilbaud P., Pellequer J.-L., Vidaud C., Quéméneur E., Structural insights into protein-uranyl interaction: towards an in-silico detection method. Biochimie 2006, $88,1631-1638$.

[7] Vidaud C., Gourion-Arsiquaud A., Rollin-Genetet F., Torne-Celer C., Plantevin S., Pible O., Berthomieu C., Quemeneur E. Structural Consequences of Binding of $\mathrm{UO}_{2}{ }^{2+}$ to Apotransferrin: Can This Protein Account for Entry of Uranium into Human Cells. Biochemistry 2007 46, 2215-2226.

[8] Hemadi M., Ha-Duong N.T., Plantevin S., Vidaud C., El Hage Chahine J.M., Can uranium follow the iron-acquisition pathway? Interaction of uranyl-loaded transferrin with receptor 1. J. Biol. Inorg. Chem. 2010, 15, 497-504.

[9] Wang M., Ding W., Wang D., Binding mechanism of uranyl to transferrin implicated by density functional theory study. $R S C A d v .2017,7,3667$.

[10] Markich S.J., Uranium Speciation and Bioavailability in Aquatic Systems: An Overview. TheScientificWorldJo 2002, (2), 707-729.

[11] data from U.S. Geological Survey, www.usgs.us

[12] Chen J.H., Lawrence Edwards R., Wasserburg G.J., ${ }^{238} \mathrm{U},{ }^{234} \mathrm{U}$ and ${ }^{232} \mathrm{Th}$ in seawater. Earth Planet. Sc. Lett. 1986, 80 (3-4), 241-251.

[13] Rona E., Gilpatrick L. O., Jeffrey L. M., Uranium determination in sea water. EOS T. Am. Geophys. Un. 1956, 37 (6), 697-701.

[14] Ku T.L., Knauss K.G., Mathieu G.G., Uranium in open ocean: concentration and isotopic composition. Deep-Sea Res. 1977, 24 (11), 1005-1010.

[15] Guegueniat, P., Germain, P., Metivier, H., Radionuclides in the oceans: inputs and inventories., 1996, France: Les editions de physique.

[16] Soualili D., Dubois P., Gosselin P., Pernet P., Guillou M., Assessment of seawater pollution by heavy metals in the neighbourhood of Algiers: use of the sea urchin, Paracentrotus lividus, as a bioindicator. ICES J. Mar. Sci. 2008, 65, 132-139.

[17] Bernd S., The use of fish parasites as bioindicators of heavy metals in aquatic ecosystems: a review. Aquat. Ecol. 2001, 35, 245-255.

[18] Mostafa H. M., Collins K. J., Heavy metal concentrations in sea urchin tissues from Egypt, Ireland and United Kingdom. Chem. Ecol. 1995, 10 (1-2), 181-190.

[19] INTERNATIONAL ATOMIC ENERGY AGENCY, Sediment Distribution Coefficients and Concentration Factors for Biota in the Marine Environment, Technical Reports Series No. 247, 1985.

[20] INTERNATIONAL ATOMIC ENERGY AGENCY, Sediment Distribution Coefficients and Concentration Factors for Biota in the Marine Environment, Technical Reports Series No. 422, 2004.

[21] Jeffree R. A., Warnau M., Teyssié J-L., Markich S. J., Comparison of the bioaccumulation from seawater and depuration of heavy metals and radionuclides in the spotted dogfish Scyliorhinus canicula 
579

580

581

582

583

584

585

586

587

588

589

590

591

592

593

594

595

596

597

598

599

600

601

602

603

604

605

606

607

608

609

610

611

612

613

614

615

616

617

618

619

620

621

622

623

624

625

626

627

(Chondrichthys) and the turbot Psetta maxima (Actinopterygii: Teleostei). Sci. Total Environ. 2006, 368 (23), 839-852.

[22] Maloubier M., Michel H., Solari P.L., Moisy P., Tribalat M-A., Oberhaensli F.R., M-J. Dechraoui Botteine, Thomas O.P., Monfort M., Moulin C., Den Auwer C., Speciation of americium in seawater and accumulation in the marine sponge Aplysina cavernicola. Dalton Trans. 2015, 44 (47), 20584-20596.

[23] Barillet S., Adam-Guillermin C., Palluel O., Porcher J-M., Devaux A., Uranium bioaccumulation and biological disorders induced in zebrafish (Danio rerio) after a depleted uranium waterborne exposure. Environ. Pollut. 2011, 159 (2), 495-502.

[24] Eb-Levadoux Y., Frelon S., Simon O., Arnaudguilhem C. Lobinski R., Mounicou S., In vivo identification of potential uranium protein targets in zebrafish ovaries after chronic waterborne exposure. Metallomics 2017, 9 (5), 525-534.

[25] Maloubier M, Solari P.L, Moisy P, Monfort M, Den Auwer C, Moulin C., XAS and TRLIF spectroscopy of uranium and neptunium in seawater. Dalton Trans. 2015, 28 (12), 5417-5427.

[26] Kelly S. D., Kemner K. M., Brooks S. C., X-ray absorption spectroscopy identifies calcium-uranylcarbonate complexes at environmental concentrations. Geochim. Cosmochim. Ac. 2007, 71 (4), 821-834.

[27] Prat O., Vercouter T., Ansoborlo E., Fichet P., Perret P., Kurttio P., Salonen L., Uranium Speciation in Drinking Water from Drilled Wells in Southern Finland and Its Potential Links to Health Effects. Environ. Sci. Technol. 2009, 43 (10), 3941-3946.

[28] Auernheimer C., Chinchon S., Calcareous skeletons of sea urchins as indicators of heavy metals pollution. Portman Bay, Spain. Environ. Geol. 1997, 29 (1-2), 78-83.

[29] Rouane-Hacene, O., Boutiba, Z., Benaissa, M., Belhaouari B., Francour P., Guibbolini-Sabatier M.E., Risso-De Faverney C., Seasonal assessment of biological indices, bioaccumulation, and bioavailability of heavy metals in sea urchins Paracentrotus lividus from Algerian west coast, applied to environmental monitoring. Environ. Sci. Pollut. Res. 2018, 25, 11238- 11251.

[30] Warnau M., Ledent G., Temaraa A., Bouquegneaub J-M., Jangouxatc M., Dubois P., Heavy metals in Posidonia oceanica and Paracentrotus lividus from seagrass beds of the north-western Mediterranean. Sci. Total Environ. 1995, 171 (1-3), 95-99.

[31] Warnau M, Teyssié JL, Fowler SW., Biokinetics of selected heavy metals and radionuclides in the common Mediterranean echinoid Paracentrotus lividus: sea water and food exposures. Mar. Ecol. Prog. Ser. 1996, 141, 83-94.

[32] Hayley M., Emberley J., Davis P.J., Morrow M.R., Robinson J.J., Interaction of Toposome from SeaUrchin Yolk Granules with Dimyristoyl Phosphatidylserine Model Membranes: A ${ }^{2}$ H-NMR Study. Biophys J. 2006, 91 (12), 4555-4564.

[33] Castellano I., Migliaccio O., Ferraro G., Maffioli E., Marasco D., Merlino A., Zingone A., Tedeschi G., Palumbo A., Biotic and environmental stress induces nitration and changes in structure and function of the sea urchin major yolk protein toposome. Sci. Rep. 2018, 8 (1), 4610.

[34] Noll H., Alcedo J., Daube M., Frei E., Schiltz E.,Hunt J.,Humphries T.,Matranga V., Hochstrasser M., Aebersold R., Lee H., Noll M., The toposome, essential for sea urchin cell adhesion and development, is a modified iron-less calcium-binding transferrin. Dev. Biol. 2007, 310 (1), 54-70.

[35] Cervello M., Matranga V., Evidence of a precursor-product relationship between vitellogenin and toposome, a glycoprotein complex mediating cell adhesion. Cell. Differ. Dev. 1989, 26(1), 67-76.

[36] LLorens I., Solari P. L., Sitaud B., Bes R., Cammelli S., Hermange H., Othmane G., Safi S., Moisy P., Wahu S., Bresson C., Schlegel M. L., Menut D., Bechade J.-L., Martin P., Hazemann J.-L., Proux O., Den Auwer C., X-ray absorption spectroscopy investigations on radioactive matter using MARS beamline at SOLEIL synchrotron, Radiochim. Acta 2014, 102 (11), 957-972.

[37] Ravel B., Newville M., ATHENA, ARTEMIS, HEPHAESTUS: data analysis for X-ray absorption spectroscopy using IFEFFIT, J. Synchrotron Radiat. 2005, 12 (4), 537-541.

[38] Michalowicz A., Moscovici J., Muller-Bouvet D., Provost K., MAX: multiplatform applications for XAFS, J. Phys.: Conf. Series, 2009, 190, 012034. 
628 [39] Bluhm H., Andersson K., Araki T., Benzerara K., Brown Jr. G. E., Dynes J. J., Ghosal S., Hansen H.629 Ch., Hemminger J. C., Hitchcock A. P., Ketteler G., Kneedler E., Lawrence J. R., Leppard G. G., Majzlam 630 J., Mun B. S., Myneni S. C. B., Nilsson A., Ogasawara H., Ogletree D. F., Pecher K., Shuh D. K., Salmeron 631 M., Tonner B., Tyliszczak T., Yoon T. H., Soft X-ray Microscopy and Spectroscopy at the Molecular 632 Environmental Science Beamline of the Advanced Light Source, J. Electron Spectros. Rel. Phenom. 2006, $633150(2-3), 86-104$.

634 [40] Maloubier M., Shuh D. K., Minasian S. G., Pacold J. I., Solari P.-L., Michel H., Oberhaensli F., Bottein 635 Y., Monfort M., Moulin C., Den Auwer C., How do Radionuclides Accumulate in Marine Organisms? A 636 Case Study of Europium with Aplysina Cavernicola, Environ. Sci. Technol. 2016, 50 (19), 10730-10738.

637 [41] Dumas T., Guillaumont D., Fillaux C., Scheinost A., Moisy P., Petit S., Shuh D. K., Tyliszczak T., Den 638 Auwer C., The Nature of Chemical Bonding in Actinide and Lanthanide Ferrocyanides Determined by X639 ray Absorption Spectroscopy and Density Functional Theory, Phys. Chem. Chem. Phys. 2016, 18 (4), 28876402895.

641 [42] http://unicorn.mcmaster.ca/aXis2000.html

642 [43] A. L. Drozdov V. V. Sharmankina L. A. Zemnukhova N. V. Polyakova. Chemical composition of 643

644

645

646

647

648

649

650

651

652

653

654

655

656

657 spines and tests of sea urchins. Biology Bull. 2016, 43 (6), 521-531.

[44] Yohey S., Jillian F. Banfield Resistance to, and Accumulation of, Uranium by Bacteria from a Uranium-Contaminated Site. Geomicrobiol. J. 2004, 21 (2), 113-121.

[45] Merroun M. L., Selenska-Pobell S., Bacterial interactions with uranium: An environmental perspective. J. Contam. Hydrol. 2008, 102 (3-4), 285-295.

[46] Pierrefite-Carle V, Santucci-Darmanin S, Breuil V, Gritsaenko T, Vidaud C, Creff G, Solari PL, Pagnotta S, Al-Sahlanee R, Den Auwer C, Carle GF., Effect of natural uranium on the UMR-106 osteoblastic cell line: impairment of the autophagic process as an underlying mechanism of uranium toxicity. Arch Toxicol. 2017, 91 (4), 1903-1914.

[47] Montavon G., Apostolidis C., Bruchertseifer F., Repinc U., Morgenstern A., Spectroscopic study of the interaction of U(VI) with transferrin and albumin for speciation of U(VI) under blood serum conditions. J. Inorg. Biochem. 2009, 103 (12), 1609-1616.

[48] Noll H., Matrangat V., Cervellot M., Humphreys T., Kuwasaki B., Adelson D., Characterization of toposomes from sea urchin blastula cells: A cell organelle mediating cell adhesion and expressing positional information. Proc. Natl. Acad. Sci. USA, 1985, 82 (23), 8062-8066. 